\title{
Effects of Different Oxygen Saturation on Activity of Complex Biomass and Aqueous Crude Extract of Cyanobacteria During Embryonal Development in Carp (Cyprinus carpio L.)
}

\author{
M. PALÍKOVÁ ${ }^{1}$, R. KREJČÍ ${ }^{2}$, K. HILSCHEROVÁ ${ }^{3}$, B. BURÝS̆KOVÁ ${ }^{3}$, P. BABICA $^{3}$, S. NAVRÁTIL $^{1}$, \\ R. KOPP ${ }^{2}$, L. BLÁHA ${ }^{3}$ \\ ${ }^{1)}$ Department of Veterinary Ecology and Environmental Protection, University of Veterinary \\ and Pharmaceutical Sciences, Brno, Czech Republic \\ ${ }^{2)}$ Department of Fishery and Hydrobiology, Mendel University of Agriculture and Forestry in Brno, \\ Czech Republic \\ 3) Center for Cyanobacteria and their Toxins (Institute of Botany, Czech Academy of Sciences; RECETOX, \\ Masaryk University in Brno), Czech Republic
}

Received February 6, 2006

Accepted February 20, 2007

\begin{abstract}
Palíková M., R. Krejčí, K. Hilscherová, B. Burýšková, P. Babica, S. Navrátil, R. Kopp, L. Bláha: Effects of Different Oxygen Saturation on Activity of Complex Biomass and Aqueous Crude Extract of Cyanobacteria During Embryonal Development in Carp (Cyprinus carpio L.) Acta Vet. Brno 2007, 76: 291-299.

This study evaluates the effects of different oxygen concentrations on the toxicity of complex cyanobacterial biomass and aqueous extract of two cyanobacterial samples (prepared with regard to the content of the most studied cyanobacterial toxin microcystin: biomass 1 with the content of microcystins $2560 \mu \mathrm{g} \cdot \mathrm{l}^{-1}$ of dry weight and biomass 2 with the content of microcystins $70 \mu \mathrm{g} \cdot \mathrm{l}^{-1} \mathrm{of}$ dry weight, i.e. almost 37-times lower concentration) during embryonal development of carp (Cyprinus carpio). Effects of complex biomass and aqueous extract were tested at concentrations 120,80 and $40 \mathrm{mg} \cdot 1^{-1}$ in four replicates, two of them aerated and two without aeration. The studied endpoints included the beginning and the end of embryo hatching, the presence of eye points at $48 \mathrm{~h}$ after fertilization, filling of air bladder, cumulative mortality and glutathione- $S$-transferase (GST) activities in surviving embryos. There was a significant increase in mortality in all variants without aeration after exposure to cyanobacterial biomass and aqueous extract $(p \leq 0.01)$. The variants with aeration at greater cyanobacterial concentrations also lead to a significant mortality increase $(p \leq 0.05)$. There was a decreased number of hatched embryos or no hatching at all in the non-aerated exposure variants for both biomasses. The lack of eye pigmentation $48 \mathrm{~h}$ after fertilization was observed at biomass concentrations of 120 and $80 \mathrm{mg} \cdot \mathrm{l}^{-1}$ for all non-aerated biomass exposures. There were fewer individuals with filled air bladder at the greatest tested concentrations of the complex biomass (biomass 1 and 2) and concentration of $80 \mathrm{mg} \cdot \mathrm{l}^{-1}$ (biomass 1 ) in the aerated variants. The activity of detoxification enzyme GST was studied during the experiment. GST activity was increased in treatments compared to control group in all aerated variants, but the changes were not always significant. The results of the conducted experiments clearly showed the important impact of oxygen saturation in water on the extent of cyanobacterial biomass toxicity. Mortality of fish eggs and embryos in experimental groups without aeration was significantly higher than in groups with aeration. Apart from the influence of toxic substances contained in the cyanobacterial biomass and the crude extract, oxygen deficiency affected the mortality in the groups without aeration.
\end{abstract}

GST activity, mortality, ammonia, hatching, embryonal toxicity test

The modes of action of cyanobacterial toxicity for aquatic organisms including fish can be very diverse. To evaluate the specific risk posed by cyanotoxins, it is necessary to understand their chemical and physical properties, monitor their occurrence in waters for human use, and regulate their production in natural ecosystems (Chorus et al. 2000).

It is difficult to attribute mortality in natural populations of aquatic organisms, especially fish, unambiguously to the effects of cyanotoxins. One of the major reasons for death of the 
aquatic organisms during water bloom collapse can be low concentrations of dissolved oxygen caused by increased metabolism of bacterial populations decomposing the dead cyanobacterial cells ( V o s and Roos 2005; S ny der at al. 2002; B arica 1978). Controlled laboratory tests with exposure of experimental animals to toxic cyanobacteria or their dissolved toxins are necessary to evaluate the potential toxic effect of cyanobacteria on aquatic organisms (Sivonen and Jones 1999).

There are a number of studies on the toxicity of microcystins and complex cyanobacterial samples to fish (Rodger et al. 1994; Tencalla et al. 1994; Carbis et al. 1997; Oberemm et al. 1999; Liu et al. 2002; Palíková et al. 2003). Even though results of some studies link the toxic effect directly to the presence of microcystins, there are some indications that the toxicity could be influenced by other factors related to the complex structure of cyanobacterial biomass (Feuillade et al. 1996; Best et al. 2001; Jungmann 1995; Mankiewicz et al. 2002). Aside from the presence of numerous unknown secondary metabolites, some of the important indicators can be the depletion of dissolved oxygen, high pH value or high toxicity of ammonia (Seymour 1980; Kopp and Heteša 2000).

Toxic cyanobacterial metabolites can induce oxidative stress, and measurement of biomarkers such as detoxification enzyme glutathione-S-transferase (GST) could be used for an early detection of adverse effects related to toxic cyanobacteria exposure. Previous studies have shown modulation of GST in fish exposed to toxic cyanobacteria with various response trends including both inhibition and induction (Wieg and et al. 1999; Piets ch et al. 2001; Best et al. 2002; Li et al. 2003; Bláha et al. 2004).

Methodology of the laboratory experiments is mostly based on the valid testing standard for the individual countries or OECD standards. The embryolarval toxicity tests in fish are described in the OECD 212 guideline (Original Guideline, adopted 1998). The experiments with cyanobacterial complex biomass or individual fractions bring into the test solutions organic material, which can be subject to microbial decomposition and can negatively affect the testing conditions. The valid OECD methodology does not allow adjusting the concentrations of dissolved oxygen by aeration and does not require monitoring of the concentration of toxic ammonia, which can be evolved during biomass decomposition and which can significantly influence the test results.

The aim of this study was to examine whether the toxicity of complex cyanobacterial biomass and its aqueous extract in carp embryonal test can be influenced by different levels of oxygen saturation.

\section{Materials and Methods}

\section{Carp eggs}

Fertilized and unstuck carp eggs were obtained by artificial spawning from fishpond cultivation in Pohořelice ltd. The production lines of carp (female PL, male M72) were used for spawning. The fish eggs were randomly assigned to treatment groups (15 eggs each) and exposed within $8 \mathrm{~h}$ of fertilization.

Characterization of used biomasses and fractions

Two different natural cyanobacterial water blooms were collected with a plankton net and stored frozen at $-18^{\circ} \mathrm{C}$. The origin of biomass and more details on the species composition are listed in Table 1.

Table 1. Characterisation of used biomass

\begin{tabular}{|c|c|c|l|l|}
\hline & Locality & Date & \multicolumn{1}{|c|}{ Dominant species } & \multicolumn{1}{c|}{ MC content } \\
\hline 1 & Brno reservoir & $10 / 1 / 1999$ & $\begin{array}{l}\text { Microcystis aeruginosa }(98 \%), \\
\text { Microcystis wesenbergii }(2 \%)\end{array}$ & $\begin{array}{l}\text { 2560 } \mu \mathrm{g} / \mathrm{g} \text { DW (MC-LR 48\%; } \\
\text { MC-YR 9\%; MC-RR 7\%; MC- } \\
\text { LW 1\%; unidentified MCs 35\%) }\end{array}$ \\
\hline 2 & Fraumühln & $7 / 29 / 1996$ & $\begin{array}{l}\text { Microcystis wesenbergii (85\%), } \\
\text { Microcystis sp. (15\%) }\end{array}$ & $70 \mu \mathrm{g} / \mathrm{g}$ DW (MC-RR 100\%) \\
\hline
\end{tabular}


After thawing, biomass concentration of each sample was adjusted to $6 \mathrm{~g}$ of dry weight per litre by dilution with distilled water. Complex fresh cyanobacterial biomass was homogenized by sonication on a magnetic stirrer, using the ultrasonic probe Bandelin Sonoplus HD2070 (15 min, cycle 0.9, 100\% power). The Homogenate was used as complex homogenized biomass for toxicity assessment or centrifuged (15 min, $2880 \mathrm{~g}$ ). The supernatant was separated, refilled with distilled water to the original volume before centrifugation and stored frozen as a crude aqueous extract.

Experimental design and conditions

The complex biomass and extract of the two different cyanobacterial samples were tested at concentrations of 120,80 and $40 \mathrm{mg}$ cyanobacterial dry weight $\cdot 1^{-1}$. Each concentration as well as control with diluting water was tested always in four replicates, two of them aerated and two without aeration. The aeration was ensured by careful micro-bubble aeration to prevent damage of the eggs. Every exposure group containing 15 carp eggs was incubated in glass vial with $15 \mathrm{ml}$ of diluting water prepared according to the standard norm ČSN EN ISO 7346. The exposure solution was renewed by semi-static methodology every $12 \mathrm{~h}$. The carp eggs and embryos were transferred with a soft net. The experiment was performed according to the OECD standard 212 (1998). The media temperature was kept at $23.5 \pm 0.3$ and the $\mathrm{pH}$ was within $7.5 \pm 0.3$ during the experiment.

The photoperiod was $14 \mathrm{~h}$ daylight and $10 \mathrm{~h}$ dark with standard laboratory light of 100 - 130 Lux intensity. The dissolved oxygen concentration was monitored during the experiments by the membrane probe WTW $315 i$ (Germany) prior to each exposure renewal. The concentration of toxic ammonia was determined by spectrophotometric method with Nessler reagent (Standard Methods 1980) prior to each exposure renewal. The concentrations of $\mathrm{NH}_{3}$ were between $0-0.13 \mathrm{mg} \cdot \mathrm{l}^{-1}$ in the different treatments. Experiments were terminated after $120 \mathrm{~h}$ when filling of the air bladder was completed in the control fish and when the fish became able to ingest feed.

Embryotoxicity

The following endpoints were studied during the test: time of the start and the end of embryo hatching, numbers of embryos hatching each day and the presence of eye spots $48 \mathrm{~h}$ after fertilization. Number of healthy embryos, filling of the air bladder, number of malformed individuals and cumulative mortality were evaluated at the end of the exposure. Surviving embryos were immediately frozen at $-80{ }^{\circ} \mathrm{C}$ for enzymatic analysis.

Biomarker methods

Glutathione- $S$-transferase activity was measured spectrophotometrically using 1-chloro-2, 4-dinitrobenzene (CDNB) as a substrate, according to the method of Habig et al. (1974). Specific activity was expressed as nmoles of product formed per minute per milligram protein. The protein concentration was determined according to the method of Lowry (1951). The GENios microplate reader (TECAN GmbH, Switzerland) was used for measurement of absorbance.

Statistical evaluation

Results were statistically analysed by Student's $t$-test and $\chi^{2}$ - test, using the STATplus software (Matoušk ová et al. 1992) and using Analysis of Variance (ANOVA) followed by Scheffe test.

\section{Results}

Cumulative mortalities after exposure to both biomasses with or without aeration are listed in Fig. 1. All concentrations of the extract caused highly significant mortality $(p \leq 0.01)$ compared to the control. Also the aerated exposure variants caused increased mortality $(p \leq 0.05)$, but only in groups exposed to the highest concentrations.

There was only limited embryo hatching or no hatching at all in non-aerated exposures. The aerated variants for complex biomass 1 at $40 \mathrm{mg} \cdot \mathrm{l}^{-1}$ caused delayed embryo hatching, compared to the control. The beginning and the end of hatching in all other aerated variants were approximately the same as in controls (Table 2).

Missing eye pigmentation $48 \mathrm{~h}$ after fertilization was observed in samples treated with 120 and $80 \mathrm{mg} \cdot \mathrm{l}^{-1}$ of both biomasses when exposed without aeration. On the other hand, there were no problems with eye pigmentation in the aerated variants. Decreased number of individuals with filled air bladder was found at the greatest complex biomass concentration (biomass 1 and 2) and at $80 \mathrm{mg} \cdot \mathrm{l}^{-1}$ for biomass 1 in the aerated exposures. The air bladder was completely filled in surviving embryos of all other treatment variants (Table 3).

The oxygen concentration was within $86-98 \%$ saturation in aerated treatments during the experiment. Despite the water renewal every $12 \mathrm{~h}$, oxygen saturation in water decreased below $60 \%$ in the non-aerated treatments with biomass or their extracts. A decrease to 


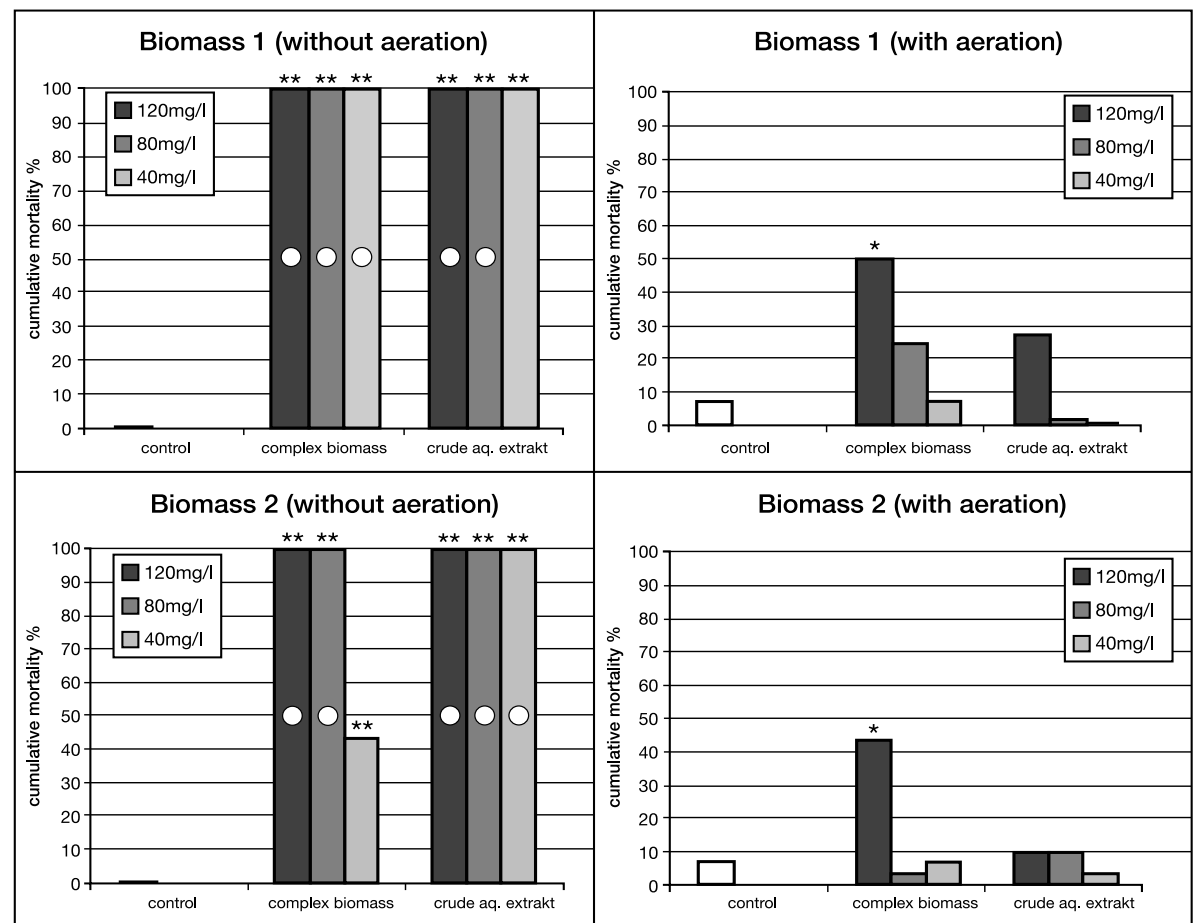

Fig. 1. Cumulative mortality after $120 \mathrm{~h}$ exposure to two biomasses at dry weight concentrations of $40,80 \mathrm{and} 120 \mathrm{mg} \cdot 1^{-1}$ with and without aeration. The significant differences from control are marked by one star $(p \leq 0.05)$, or two stars $(p \leq 0.01)$. Variants with oxygen level decreased below the validity value of $60 \%$ are marked by a circle

Table 2. Effect of exposures on carp embryo hatching. (A) complex biomass, (B) crude aquatic extract

\begin{tabular}{|c|c|c|c|c|c|c|c|c|c|}
\hline \multirow[t]{3}{*}{ Biomass } & \multirow{3}{*}{$\begin{array}{l}\text { Bomass dry } \\
\text { weight conc. } \\
\left(\mathrm{mg} \cdot \mathrm{l}^{-1}\right)\end{array}$} & \multicolumn{4}{|c|}{ Beginning of hatching (hours) } & \multicolumn{4}{|c|}{ End of hatching (hours) } \\
\hline & & \multicolumn{2}{|c|}{ with aeration } & \multicolumn{2}{|c|}{ without aeration } & \multicolumn{2}{|c|}{ with aeration } & \multicolumn{2}{|c|}{ without aeration } \\
\hline & & $\mathrm{A}$ & $\mathrm{B}$ & $\mathrm{A}$ & $\mathrm{B}$ & $\mathrm{A}$ & $\mathrm{B}$ & $\mathrm{A}$ & $\mathrm{B}$ \\
\hline \multirow{3}{*}{1} & 120 & 68.5 & 71.0 & - & - & - & 84.5 & - & - \\
\hline & 80 & 56.5 & 62.5 & - & - & 73.0 & 76.5 & - & - \\
\hline & 40 & 67.0 & 65.0 & - & 94.0 & 93.5 & 80.0 & - & - \\
\hline \multirow{3}{*}{2} & 120 & 63.5 & 58.0 & - & - & - & 71.0 & - & - \\
\hline & 80 & 52.0 & 55.5 & - & - & 74.0 & 69.0 & - & - \\
\hline & 40 & 58.0 & 58.0 & 90.0 & 93.6 & 74.0 & 84.0 & - & - \\
\hline control & - & \multicolumn{2}{|c|}{62.0} & \multicolumn{2}{|c|}{67.0} & \multicolumn{2}{|c|}{74.0} & \multicolumn{2}{|c|}{84.0} \\
\hline
\end{tabular}

Table 3. Absence of eye pigmentation and incomplete filling of air bladder in exposure variants: (A) complex biomass. (B) crude aq. extract. Numbers in parentheses are dry weight concentrations $\left(\mathrm{mg} \cdot \mathrm{l}^{-1}\right)$. N.D. $=$ not detected

\begin{tabular}{|c|c|c|c|}
\hline \multicolumn{2}{|c|}{ Biomass } & $\begin{array}{c}\text { Absence of eye pigmentation } \\
\text { at } 48 \mathrm{~h}(\%)\end{array}$ & $\begin{array}{c}\text { Filling of air bladder } \\
\text { after } 120 \mathrm{~h}(\%)\end{array}$ \\
\hline \multirow{3}{*}{1} & with aeration & N.D. & A (80) $80 \% .(120) 85 \%$ \\
\cline { 2 - 4 } & without aeration & A. B (120.80) $100 \%$ & $100 \%$ mortality \\
\cline { 2 - 4 } & & A. B (40) $75 \%$ & A (120) $75 \%$ \\
\hline \multirow{3}{*}{2} & with aeration & N.D. & $100 \%$ mortality \\
\cline { 2 - 4 } & without aeration & A. B (120.80) $100 \%$ & A. B (40) $70 \%$ \\
\hline
\end{tabular}


Table 4. Decrease of oxygen saturation (in hours of exposure renewal)

\begin{tabular}{|c|c|c|c|}
\hline \multirow{2}{*}{ Biomass } & $\begin{array}{c}\text { Biomass dry weight } \\
\text { conc. }\left(\mathrm{mg} \cdot \mathrm{l}^{-1}\right)\end{array}$ & complex biomass & crude aquatic extract \\
\hline \multirow{3}{*}{1} & 120 & 72 & 72 \\
\cline { 2 - 4 } & 80 & 72 & 72 \\
\cline { 2 - 4 } & 40 & 96,108 & 60 \\
\cline { 2 - 4 } 2 & 120 & $24,36,48,60,72$ & 84 \\
\cline { 2 - 4 } & 80 & 84 & 108 \\
\hline
\end{tabular}

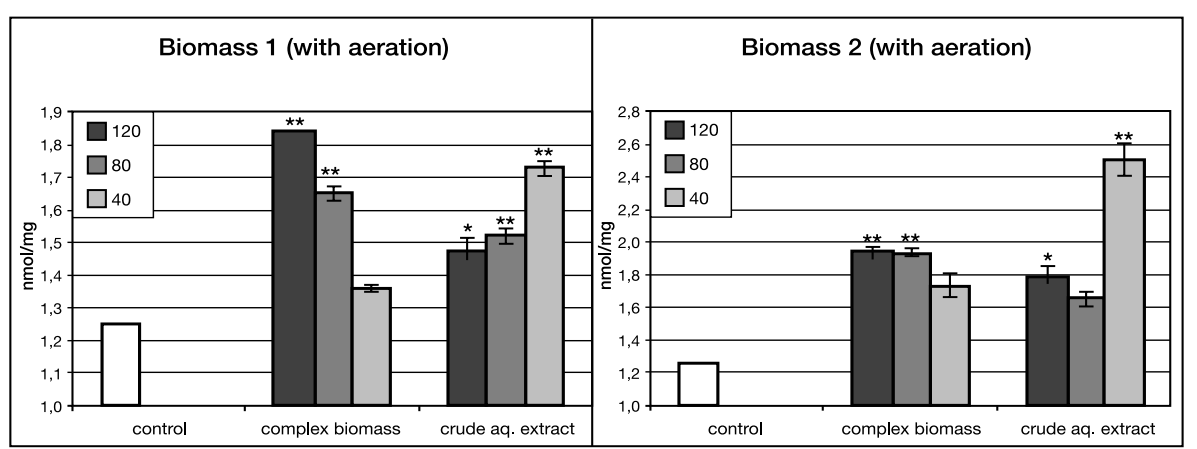

Fig. 2. Activity of glutathione- $S$-transferase (GST) after $120 \mathrm{~h}$ exposure to two cyanobacterial biomasses at dry weight concentrations 40,80 and $120 \mathrm{mg} \cdot \mathrm{l}^{-1}$ with aeration. The significant differences from control are marked by one star $(p \leq 0.05)$, or two stars $(p \leq 0.01)$. Bars represent means \pm standard error of the mean of two independent experiments.

$45-58 \%$ saturation was observed in all non-aerated exposures except for the dry weight concentration of $40 \mathrm{mg} \cdot \mathrm{l}^{-1}$ of the aqueous extract (biomass 1 ) and complex biomass (sample 2 ). The oxygen saturation was in the range of $60-88 \%$ in all other variants as well as in controls without aeration. The decrease of oxygen saturation is presented in the Table 4 .

Glutathione- $S$-transferase (GST)

The experimental setup included determination of the detoxification enzyme GST activity in the embryos at the end of exposure. We observed an increase in the enzyme activities in embryos from all aerated exposures, but some of these changes were not statistically significant (Fig. 2).

\section{Discussion}

The results of the conducted experiments clearly showed an important impact of oxygen saturation in water on the extent of cyanobacterial biomass toxicity in the embryonal test with carp. The oxygen saturation decreased below $60 \%$ after exposure to complex biomass or aqueous extract of both biomasses in the non-aerated variants (Fig. 1). Thus results of these tests cannot be considered valid according to the standard OECD 212 (1998) due to the oxygen decrease. However, fish mortality was observed also in cases where the oxygen concentration was over $60 \%$ during the entire experiment both in the groups with and without aeration.

The positive effect of higher oxygen concentration in evaluation of important contaminants of the aquatic environment, in accordance with toxic effect reduction, has been shown previously. Witeska and Jezierska (2003) summarize the effect of environmental factors on the extent of heavy metal toxicity in fish. Fish are more sensitive to intoxication under hypoxic conditions. Higher sensitivity of carp to toxic effects of 
cadmium was observed in hypoxic conditions compared to normal oxygen levels (Hattink et al. 2005).

The amount of oxygen in water strongly affects the toxicity of ammonia, too. The $\mathrm{LC}_{50}$ value for $\mathrm{NH}_{3}$ in smolts of salmon (Salmo salar L.) was $0.20 \mathrm{mg} \cdot \mathrm{l}^{-1}$ at oxygen concentration of $10 \mathrm{mg} \cdot \mathrm{l}^{-1}$ and $0.08 \mathrm{mg} \cdot \mathrm{l}^{-1}$ at $3.5 \mathrm{mg} \cdot \mathrm{l}^{-1}$ dissolved oxygen, respectively (Alab a ster et al. 1983). Similar trend of decreasing ammonia toxicity at greater oxygen concentrations was reported for rainbow trout (Oncorhynchus mykiss) (Thurson et al. 1981; Magaud et al. 1997), three species of freshwater fish (Richardson et al. 2001) or juvenile sea bass (Dicentrarchus labrax L.) (Tudor et al. 1994). Toxic ammonia is formed in exposures with cyanobacterial biomass and it can have a negative effect on the studied toxicological indicators (Kopp and Heteša 2000). There are no literature data on ammonia toxicity to carp eggs and embryos, and the oxygen saturation level at which the ammonia toxicity increases is not known. Our experiments studying the effect of ammonia on carp eggs and embryos (unpublished results) showed no toxic effects of non-dissociated ammonia at concentrations of $0.04-0.18 \mathrm{mg} \cdot \mathrm{l}^{-1}$ at over $85 \%$ oxygen saturation. It is possible that a slightly increased ammonia concentration will not cause acute toxic effects, but it could lead to chronic effects associated with worsened environmental conditions (poorer oxygen saturation and presence of other xenobiotics that may weaken the organism). In our experiments, non-dissociated ammonia did not exceed the concentration of $0.13 \mathrm{mg} \cdot \mathrm{l}^{-1}$ in any group (see Materials and Methods), but poorer oxygen saturation may have influenced the ammonia toxicity. In case of aerated exposures, however, the oxygen concentration was high, but there was still some increased mortality, namely at the greatest tested concentrations of complex biomass and extract, which could not be caused either by toxic ammonia or poorer oxygen saturation.

High oxygen concentration in water can also affect the toxicity of other compounds that can evolve as intermediates of decomposition of organic compounds during exposure, or other unidentified toxic compounds produced by cyanobacteria. An important factor in aerated variants is also the continuous motion of water in experimental flasks, preventing the settling of particles on the egg surface. Complex biomass includes also cellular walls that could settle on the fish eggs. Some precipitation of unspecified compounds originating from the cellular content of cyanobacteria occurred during the exposure. These aggregates can limit the oxygen exchange between fish eggs and the environment and can lead to egg mortality.

Although the blue-green algae are a natural part of ecosystems, current scientific research documents that fish incline to react to their biomass and metabolites as to xenobiotics. Detoxification processes are modulated and some potentially dangerous processes can be activated. The detoxification kinetics is strongly time-dependent - the acute exposures lead to a decrease of antioxidants, whereas longer chronic exposures can stimulate protective processes (Bláha et al. 2004). The increase in detoxication enzyme activities linked to biotransformation of toxic substances is connected with an increased respiration need caused by xenobiotic stress in fish ( Schmidt et al. 2005).

Changes in the activity of the detoxification enzyme glutathione- $S$-transferase (GST) could indicate damage by toxic cyanobacteria to fish organism. The activity of GST in our experiments elicited an increasing trend, compared to the control group. It can be stated that cyanobacteria induce the activity of GST, but the GST is activated regardless of the quantity of microcystins. Research on the response of the antioxidative system in hepatocytes of carp (Cyprinus carpio) to a microcystin-LR exposure has shown significant increases in the concentration of reactive oxygen species (ROS), and superoxide dismutase (SOD), catalase (CAT) and glutathione peroxidase (GSH-Px) activities and a significant decrease in glutathione (GSH) levels, but no significant modulation in GST activity (Li et al. 2003). 
Similar unclear effect of MC-LR exposure on the GST was shown in early life stages of zebra fish (Danio rerio) (Wiegand et al. 1999). On the other hand, Pietsch et al. (2001) reported a significant decrease in the GST activities zebra fish (Danio rerio) after 24-h exposure of fish eggs to cyanobacterial extract, whereas a significant increase of GST was observed after exposure to purified MC-LR and MC-RR. A statistically significant decrease was observed in case of co-exposure of zebra fish to cyanobacterial lipopolysacharides (LPS) and MC-LR (B est et al. 2002). Comparison of our results with literature data confirms obvious time-dependency of the modulation of detoxification processes, when early life stages of fish are exposed to toxicants. An increase or decrease of GST activity caused by stimulation or inhibition of protective processes can be observed depending on the exposure duration (Pietsch et al. 2001; Best et al. 2002).

There were no great differences in mortality, process of hatching and GST activity between biomass 1 with the microcystin content of $2560 \mu \mathrm{g} \cdot \mathrm{l}^{-1} \mathrm{DW}$ and biomass 2 with the microcystin content of $70 \mu \mathrm{g} \cdot \mathrm{l}^{-1} \mathrm{DW}$. This indicates that the toxic effect was not caused directly by microcystins and that more factors influence the toxic effect. Even though there was no significant relationship between the observed mortality and the microcystin concentration, the biomass with greater microcystin content (biomass 1) caused increased mortality of fish eggs and embryos namely at the greatest concentrations of complex biomass or extract.

Environmental conditions, especially the concentration of oxygen and toxic ammonia, are affected by complex biomass and aqueous extract of cyanobacterial water bloom during their degradation. Our results document the obvious necessity to pay increased attention to optimal experimental conditions when testing the toxicity of important aquatic pollutants, but namely for cyanobacterial exposures. Mortality of fish eggs and embryos in experimental groups without aeration was significantly higher than in groups with aeration. Apart from the influence of toxic substances contained in the cyanobacterial biomass and the crude extract, oxygen debt took part in the mortality in the groups without aeration. That is why aeration is necessary when using experimental substances high in the dry matter content liable to aerobic decomposition in embryolarval tests. This approach, however, is in disagreement with the OECD 212 method.

\section{Vliv různé saturace kyslíkem na působení surové biomasy a extraktu sinic během embryonálního vývoje kapra obecného (Cyprinus carpio L.)}

Byl sledován vliv rozdílné výše koncentrace kyslíku na toxicitu surové biomasy a vodného extraktu sinic dvou druhů biomas sinic (připravených s ohledem na obsah nejznámějšího cyanobakteriálního toxinu, microcystinu: biomasa $1 \mathrm{~s}$ obsahem microcystinů $2560 \mu \mathrm{g} \cdot \mathrm{l}^{-1}$ sušiny a biomasa 2 obsahem microcystinů $70 \mu \mathrm{g} \cdot \mathrm{l}^{-1}$ sušiny - asi $37 \times$ nižší koncentrace) během embryonálního vývoje kapra obecného (Cyprinus carpio L.). V experimentu byla testována surová biomasa a vodný extrakt sinic v koncentracích sušiny $120,80 \mathrm{a} 40 \mathrm{mg} \cdot \mathrm{l}^{-1}$ ve čtyřech opakováních, dvě byla bez aerace a dvě s aerací. Během testů byl sledován začátek a konec kulení embryí, přítomnost očních bodů 48 h po oplození, po ukončení experimentu naplnění plynového měchýře, kumulativní mortalita a u přeživších jedinců i aktivita glutathion-S-transferázy (GST). Ve všech pokusných koncentracích bez aerace došlo k signifikantnímu nárůstu $(p \leq 0,01)$ mortality. U variant s aerací rovněž došlo u nejvyšších koncentrací surové biomasy a extraktu k nárůstu mortality $(p \leq 0,05)$. U všech pokusných variant bez aerace obou biomas došlo k vykulení pouze omezeného množství embryí nebo k vykulení embryí vůbec nedošlo. Byla zaznamenána absence oční pigmentace po $48 \mathrm{~h}$ po oplození u koncentrací sušiny 120 a $80 \mathrm{mg} \cdot \mathrm{l}^{-1} \mathrm{u}$ všech variant bez aerace. Byl zjištěn snížený počet jedinců s naplněným plynovým měchýřem v nejvyšší koncentraci surové biomasy (bioma- 
sa 1 a 2) a koncentraci $80 \mathrm{mg} \cdot \mathrm{l}^{-1}$ (biomasa 1 ) u variant s aerací. V rámci experimentů byla sledována i aktivita detoxikačního enzymu GST. Zvýšení aktivity detoxikačního enzymy GST bylo zaznamenáno u všech variant s aerací ve srovnání s kontrolní skupinou, změny však nebyly vždy signifikantní. Výsledky provedených experimentů jasně prokázaly vysoký vliv koncentrace kyslíku ve vodě na míru toxicity biomas sinic. V pokusných skupinách bez aerace byla mortalita jiker a embryí signifikantně vyšší než ve skupinách s aerací. Na mortalitě ve skupinách bez aerace se kromě vlivu toxických látek obsažených v biomase sinic a v extraktu podílel i kyslíkový deficit.

\section{Acknowledgement}

The research was supported by the Research Project of the Ministry of Education, Youth and Sports of the Czech Republic "Veterinary aspects of food safety and quality" MSM 6215712402 and by the project AVOZ60050516 granted to the Institute of Botany.

\section{References}

ALABASTER JS, SHURBEN DG, MALLETT MJ 1983: The acute lethal toxicity of mixtures of cyanide and ammonia to smolts of salmon, Salmo salar L. at low concentrations of dissolved-oxygen. J Fish Biol 22: 215-222

BARICA J 1978: Collapses of Aphanizomenon flos-aquae blooms resulting in massive fish kills in eutrophic lakes, effects of weather. Verh Internat Verein Limnol 20: 208-213

BEST JH, EDDY FB, CODD GA 2001: Effects of purified microcystin- LR and cell extracts of Microcystis strains PCC 7813 and CYA 43 on cardiac function in brown trout (Salmo trutta) alevins. Fish Physiol Biochem 24(3):171-178

BEST JH, PFLUGMACHER S, WIEGAND C, EDDY FB, METCALF JS, CODD GA 2002: Effects of enteric bacterial and cyanobacterial lipopolysaccarides and of microcystin-LR on glutathione S-transferase activities in zebra fish (Danio rerio). Aquat Toxicol 60: 223-231

BLÁHA L, KOPP R, ŠIMKOVÁ K, MAREŠ J 2004: Oxidative stress biomarkers are modulated in silver carp (Hypophthalmichthys molitrix Val.) exposed to microcystin-producing cyanobacterial water bloom. Acta Vet Brno 73: 477-482

CARBIS CR, RAWLIN GT, GRANT P, MITCHELL GF, ANDERSON JW, MCCAULEY I 1997: A study of feral carp (Cyprinus carpio L.) exposed to Microcystis aeruginosa at Lake Mokoan, Australia and possible implications for fish health. J Fish Dis 20: 81-91

CHORUS I, FALCONER IR, SALAS HJ, BARTRAM J 2000: Health risk caused by freshwater cyanobacteria in recreation waters. J Toxicol Environ Health Part B 3: 323-347

FEUILLADE M, JAHNN-PARA G, FEUILLADE J 1996: Toxic compounds to Artemia from blooms and isolates of the cyanobacterium Planktothrix rubescens. Arch Hydrobiol 138: 175-186

HABIG WM, PABST MJ 1974: Glutathione-S-transferases. The first enzymatic step in mercapturic acid formation. J Biol Chem 249: 7130-7139

HATTINK J, DE BOECK G, BLUST R 2005: The toxicokinetics of cadmium in carp under normoxic and hypoxic conditions. Aquat Toxicol 75: 1-15

JUNGMANN D 1995: Isolation, purification, and characterization of new Daphnia-toxic compound from axenic Microcystis flos-aquae strain PCC7806. J Chem Ecol 21: 1665-1676

KOPP R, HETEŠA J 2000: Changes of haematological indices of juvenile carp (Cyprinus carpio L.) under the influence of natural populations of cyanobacterial water blooms. Acta Vet Brno 69:131-137

LI X, LIU Y, SONG L, LIU J 2003: Responses of antioxidant systems in the hepatocytes of common carp (Cyprinus carpio $\mathrm{L}$.) to the toxicity of microcystin-LR. Toxicon 42: $85-89$

LIU Y, SONG L, LI X, LIU T 2002: The toxic effects of microcystin-LR on embryo-larval and juvenile development of loach, Misguruns mizolepis Gunthe. Toxicon 40: 395-399

LOWRY OH, ROSEBROUGH AL, FARR AL, RANDALL RJ 1951: Protein measurements with Folin-Phenol reagents. J Biol Chem 193: 265- 275

MAGAUDH MIGEON B, MORFIN P, GARRIC J, VINDIMIAN E 1997: Modelling fish mortality due to urban storm run-off: Interacting effects of hypoxia and un-ionized ammonia. 31: 211-218

MANKIEWICZ J, WALTER Z, TARCZYNSKA M, PALYVODA O, WOJTYSIAK- STANIASZCZYK M, ZALEWSKI M 2002: Genotoxicity of Cyanobacterial Extracts Containing Microcystins from Polish Water Reservoirs as Determined by SOS Chromotest and Comet Assay. Environ Toxicol 17: 341-350

MATOUŠKOVÁ O, CHALUPA J, CÍGLER M, HRUŠKA K 1992: Statistic system STAT plus, version 1.01. Book of reference. Veterinary Research Institute Brno, 168 p. (In Czech)

OBEREMM A, BECKER J, CODD GA, STEINBERG CEW 1999: Effects of cyanobacterial toxins and aqueous crude extract of cyanobacteria on the development of fish and amphibians. Environ Toxicol 14: 77-88

PALÍKOVÁ M, NAVRÁTIL S, MARŠÁLEK B, BLÁHA L 2003: Toxicity of crude extract of cyanobacteria for embryos and larvae of carp ( Cyprinus carpio L.). Acta Vet Brno 72: 437-443 
PIETSCH C, WIEGAND C, AMÉ MV, NICKLISCH A, WUNDERLIN D, PFLUGMACHER S 2001: The effects of a cyanobacterial crude extract on different aquatic organisms: Evidence for cyanobacterial toxin modulating factors. Environ Toxicol 16: 535-542

RICHARDSON J, WILLIAMS EK, HICKEY CW 2001: Avoidance behaviour of freshwater fish and shrimp exposed to ammonia and low dissolved oxygen separately and in combination. N Z J Mar Freshwater Res 35: 625-633

RODGER HD, TURNBULL T, EDWARDS C, CODD GA 1994: Cyanobacterial bloom associated pathology in brown trout Salmo trutta L. In: Loch Leven, Scotland. J Fish Dis 17: 177-181

SCHMIDT K, PELUGMACHER S, STAAKS GBO, STEINBERG CE 2005: Effects of subacute PCB- exposure (Aroclor 1254) on oxygen consumption, swimming behavior and biotransformation (GST-activity) of carp (Cyprinus carpio). (UWSF) 17: 133-145

SEYMOUR EA 1980: The effects and control of algal bloom in fish ponds. Aquaculture 19: 55-74

SIVONEN K, JONES G 1999: Cyanobacterial toxins. In: Toxic Cyanobacteria in Water: A guide to their public health consequences, monitoring and management. J. Editors Chorus I. Bartram. London: E\&FN Spon. pp. 41-111

SNYDER GS, GOODWIN AE, FREEDMAN DW 2002: Evidence that channel catfish Ictalurus punctatus (Rafinesque) mortality is not linked to ingestion of the hepatotoxin microcystin-LR. J Fish Dis 25: 275-285

TENCALLA GF, DIETRICH RD, SCHLATTER CH 1994: Toxicity of Microcystis aeruginosa peptide toxin to yearling rainbow trout (Oncorhynchus mykiss). Aquat Toxicol 30: 215-224

THURSTON RV, PHILLIPS GR, RUSSO RC, HINKINS SM 1981: Increased toxicity of ammonia to rainbow trout (Salmo gairdneri) resulting from reduced concentrations of dissolved oxygen. 38: 983-988

TUDOR M, KATAVIC I, LUCIC JM 1994: Acute toxicity of ammonia to juvenile sea bass (Dicentrarchus labrax L.) at different aeration levels. 128: 89-95

VAN DER OOST R, BEYER J, VERMEULEN NPE, 2003: Fish bioaccumulation and biomarkers in environmental risk assessment: a review. Environ Toxicol Pharmacol 13: 57-149

VOS AT, ROOS JC 2005: Causes and consequences of algal blooms in Loch Logan, an urban impoundment. Water SA 31(3): 385-392

WIEGAND C, PFLUGMACHER S, OBEREMM A, MEEMS N, BEATTIE KA, STEINBERG CEW, CODD GA 1999: Uptake and Effects of Microcystin- LR on Detoxication Enzymes of Early Life Stages of the Zebra Fish (Danio rerio). Environ Toxicol 14: 89-95

WITESKA M, JEZIERSKA B 2003: The effects of environmental factors on metal toxicity to fish (review). 12: $824-829$ 